\title{
Experimental study on multi-decked protuberant foil thrust bearing with different number of thrust pads
}

\author{
Tianwei LAI*, Yu GUO*, Wei WANG*, Shuangtao CHEN* and Yu HOU* \\ * State Key Laboratory of Multiphase Flow in Power Engineering, Xi'an Jiaotong University, Xi'an 710049, PR China \\ E-mail: yuhou@mail.xjtu.edu.cn
}

Received 10 June 2016

\begin{abstract}
Thrust bearing is an important component in high speed rotor bearing system. For the thrust bearing, the pad circumferential partition is recognized as an essential factor for the foil thrust bearing in hydrodynamic lubrication. In this paper, performances of multi-decked protuberant foil thrust bearing (MDPFTB) with different pad numbers were experimentally studied on a thrust bearing test rig. Static deflection, transient start-up and transient loading performance of the thrust bearings of 3 pads, 4 pads and 6 pads were compared. The test results indicated that partition of thrust pad had a significant effect on the static and transient loading characteristics of the bearing. Radial vibration of the rotor-bearing system was coupled with the axial thrust bearing support condition. The axial supporting had limited effects on the lower order critical speeds in the radial direction. However, in higher speed range, more thrust pads could increase the second and higher critical speeds and suppress the vibration amplitude. The ultimate load capacity of the bearing increased with thrust pads. However, the available operational speed range was narrowed down. For the bearing with more thrust pads, load capacity decreased earlier in high speed range with softer static stiffness. The results may provide some design guides for application of protuberant foil thrust bearing.
\end{abstract}

Key words : Load capacity, Protuberant foil, Rotor-bearing system, Thrust bearing

\section{Introduction}

Foil bearing is a kind of aerodynamic bearing with layer(s) of resilient supporting foil and compliant top foil. Comparing to conventional ball bearings, it is more competitive in high speed and extreme environment occasions (Howard, et al., 2001a ,2001b) (Hou, et al., 2004). It is widely used in high speed oil-free turbomachinery and motors owing to its stability, durability, tolerance, low power loss (Agrawal, 1997)( Sim et al., 2015a, 2015b)(Hou et al., 2015).

The rotor-bearing system usually consisted of a rotor supported by journal bearings and thrust bearings. A typical configuration of foil thrust bearings was shown in Fig. 1. In foil thrust bearing, conventionally, circular loading foils were split into a number of separated thrust pads circumferentially on account of thermal or loading conditions (Ryu and Andres, 2013)(Kim et al., 2011). Thrust pad number could be 3, 4, 6 and 8 etc. This not only modified the hydrodynamic pressure profile on the loaded thrust pad, but affected the frictional interaction between the foils. In each thrust pad, the top flat foil was supported by the elastic structure. From leading edge to trailing edge, the top foil and the supporting foil extended circumferentially with the same inner and outer diameter. The bearing stiffness depended on the gas film as well as on the configuration of the supporting elastic structure.

In foil bearing, environment-friendly fluid such as air or nitrogen was a preferred choice for lubricant. However, the inherent low viscosity of such fluid restricted the application of gas foil bearing for a long time. With development of technology and continuous retrofitting, its operating speed and load capacity have been greatly improved. Heshmat $\mathrm{H}$. et al. rectified the thrust pad profile to improve load capacity for the bump type foil bearing (Heshmat et al.,1983). Lee and Kim alleviated the dry friction at start-up and enhanced the load capacity of foil bearing via combination with hydrostatic pressurization (Lee and Kim, 2010). Zhou Q. et al. selected the foil with punched dimples as underlying spring element (Zhou et al, 2011). Balducchi F. experimentally analyzed the torque and lift-off velocity of a foil thrust bearing, and found 
that the operating torque varied almost linearly with load and operating speed (Balducchi et al., 2013). Somaya K. applied viscoelastic supports in thrust bearing (Somaya et al., 2009). Zhou Q. tested the dynamic characteristic of foil thrust bearing with viscoelastic support (Zhou et al., 2009). Following the design principles from Dellacorte C. (DellaCorte et al, 2008), Dykas B. outlined the fabrication of a modular thrust foil bearing (Dykas et al, 2009). Its load capacity was proportional to the runner surface velocity at the center of top foil and the total swept area of the bearing between the inner and outer radii of the foils. Kim D. compared the load capacity of circular top foil and three pads configuration in journal bearing (Kim, 2006). For the bearing with three pad configurations, its load capacity was reduced significantly; but its stability was improved. In the bump foil bearing, higher load and stiffness could be achieved with more bumps; however, too many bumps pinned down some or all of the bumps that resulted in little or no damping.

Foil bearing load capacity reached the asymptotic limiting load capacity at higher rotational speed. The ultimate load of the bearing could not exceed that of supporting structure (Kim and Andres, 2006). There was load capacity limit for the foil bearing (Peng and Khonsari, 2004). Keeping other parameters unchanged, steady state bearing stiffness increased with imposed load and decreased with speed (Howard et al, 2001a). With increase of bearing temperature, direct stiffness decreased by about $8 \%$ and damping by about 30\% (Sim et al, 2014b).

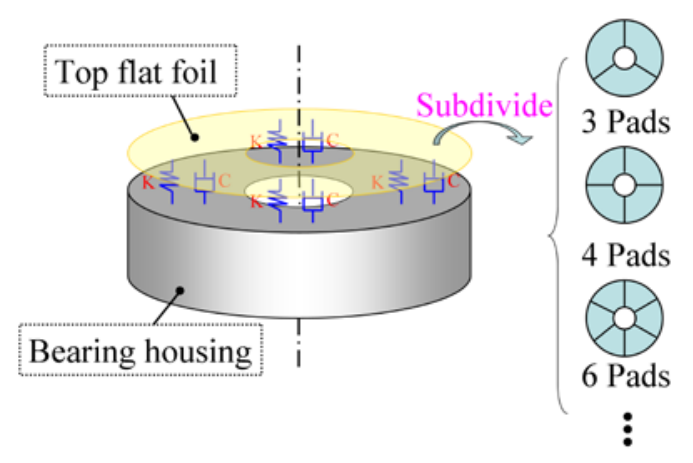

Fig. 1 Schematic diagram of foil thrust bearing

In practical operation, circular partition of thrust foil affected both hydrodynamic pressure profile and the friction between supporting foils, and then changed the bearing stiffness (Ku and Heshmat, 1992) (Ku and Heshmat, 1993). Up to now, there were a number of literatures on journal bearing concerning load capacity, stability, etc. There have been benchmarked design and test rigs for journal bearing (DellaCorte et al, 2008) (Rudloff et al, 2011) (Dellacorte, 1998) (Howard et al, 2001a) (Rubio and Andres et al, 2006). Comparing to foil journal bearing, the thrust bearing did not enjoy the same interest and development. Furthermore, with the development of higher speed turbomachinery, the challenges of thrust load and stability were pressing to be addressed. Therefore, more efforts were required for the development of high performance thrust bearing. In this manuscript, experimental studies on three thrust bearings of different pad partitions were performed to investigate the effect of pad number on their performances. The load deflection relation and static stiffness of the bearings were evaluated. In addition, rotordynamic performances of the three bearings were compared in the transient start-up and loading tests. It was of great significance for further application in high speed rotor-bearing system.

\section{Tested multi-decked protuberant foil thrust bearings}

In multi-decked thrust bearing, as shown in Fig. 2, a stack of multiple foils were used as the supporting structure. The three tested multi-decked foil thrust bearings with different number of thrust pads were shown in a), b) and c). The angular extent of thrust pads of the bearings was $120^{\circ}, 90^{\circ}$ and $60^{\circ}$, respectively. In each thrust pad, there were two layers of supporting protuberant foils (PF) under the top flat foil. The three layers of foils were pinned on the bearing housing at the outer circumferential direction. In actual situation, there will be inlet effect that raised the static pressure of the flow entering the bearing above the ambient pressure (Hughes et al, 1996). This helped the built-up of hydrodynamic gas film in each thrust pad of the bearing. At this experimental stage, replacement of foils may frequently crop up in bearing loading and unloading processes. In addition, with flat foils in the bearing, ease of 
manufacturing and assemble/dissemble were two advantages of this type of design. In the three bearings, thickness of the protuberant foil was $0.05 \mathrm{~mm}$ and the top foil was $0.07 \mathrm{~mm}$. The projections on the protuberant foils were fabricated by punching from a plain foil. For the protuberant foil journal bearing, the subsychronous vibrations could be suppressed effectively since its first application in a high speed turbo-expander (Lai et al., 2014). Therefore, similar configuration was introduced in thrust bearing.

Geometry of the upper protubereant foil was shown in Fig. 3. The angular span of the protuberant projection was $30^{\circ}$ at the inner row and was $15^{\circ}$ at the outer row, respectively. The detailed parameters of the upper and lower protuberant foils were listed in Table 1 . The only difference between the three bearings lied in the $\alpha_{\mathrm{pf}}$ which was the pad angular extent in circumferential direction.

a

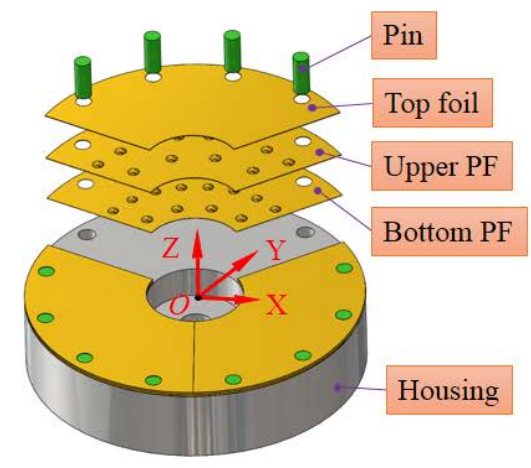

b

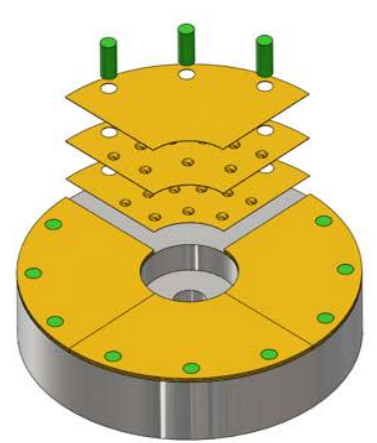

c

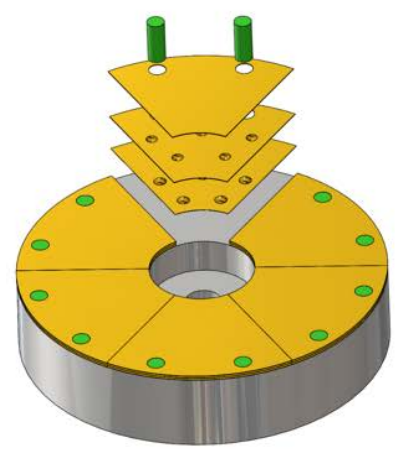

Fig. 2 Protuberant foil thrust bearing with angular extent of a) $120^{\circ}$; b) $90^{\circ}$; c) $60^{\circ}$
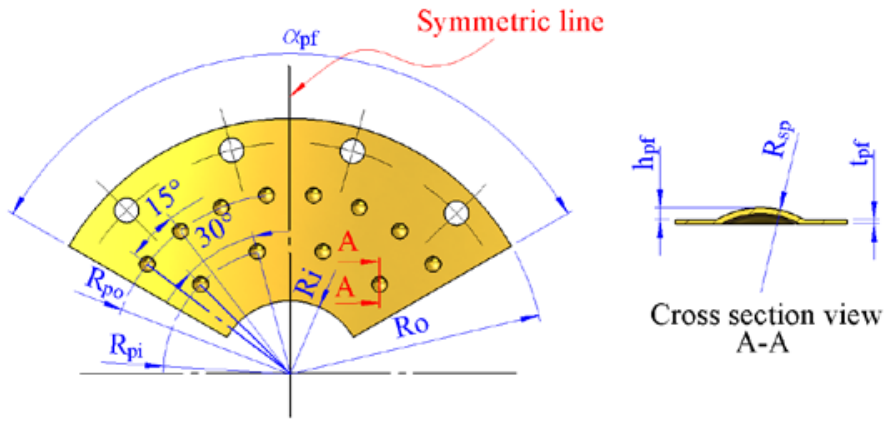

A-A

Fig. 3 Geometrical diagram of upper protuberant foil

Table 1 Detailed parameters of the protuberant foils

\begin{tabular}{|c|c|c|}
\hline \multicolumn{2}{|l|}{ Parameters } & Value \\
\hline \multicolumn{2}{|l|}{ Top foil thickness $t_{\mathrm{tf}} / \mathrm{mm}$} & 0.07 \\
\hline \multicolumn{2}{|l|}{ Protuberant foil thickness $t_{\mathrm{pf}} / \mathrm{mm}$} & 0.05 \\
\hline \multicolumn{2}{|l|}{ Number of supporting layers $N_{l}$} & 2 \\
\hline \multicolumn{2}{|l|}{ Height of protuberant convex $h_{\mathrm{pf}} / \mathrm{mm}$} & 0.3 \\
\hline \multicolumn{2}{|l|}{ Spherical radius of projections $R_{\mathrm{sp}} / \mathrm{mm}$} & 1.4 \\
\hline \multirow{2}{*}{ Radial location of inner protuberant projections $R_{\mathrm{pi}} / \mathrm{mm}$} & Upper layer & 10.4 \\
\hline & Bottom layer & 8.2 \\
\hline \multirow{2}{*}{ Radial location of outer protuberant projections $R_{\mathrm{po}} / \mathrm{mm}$} & Upper layer & 14.8 \\
\hline & Bottom layer & 12.6 \\
\hline
\end{tabular}

\section{Experimental test rig}

Dedicated gas-driven thrust bearing test rig was shown in Fig. 4 a) and b). It was renovated based on the rig in Ref 
(Zhou et al., 2009). It was composed of four systems: high speed rotor-bearing system, loading system, high pressure gas supply system and data acquisition system. High speed rotor-bearing was composed of expansion wheel, hydrostatic journal bearing and shaft. The rotor was horizontal layout and its weight was supported by two hydrostatic journal bearings. Reaction type expansion wheel converted the high pressure potential energy into kinetic rotation. At the other end of high speed rotor there was a thrust runner that pairs with the tested thrust bearing. The thrust bearing was connected with the piston type loading cell. The rotor-bearing system and loading cell were installed on a mass base and positioned on precise guide rail. For proper alignment, the stainless supporting were finished in one piece and split into parts. The high pressure gas came from a double screw air compressor. The vibrations of the rotor in radial (X and $\mathrm{Y}$ ) and axial (Z) directions were captured and processed by a computerized data acquisition/processing system.

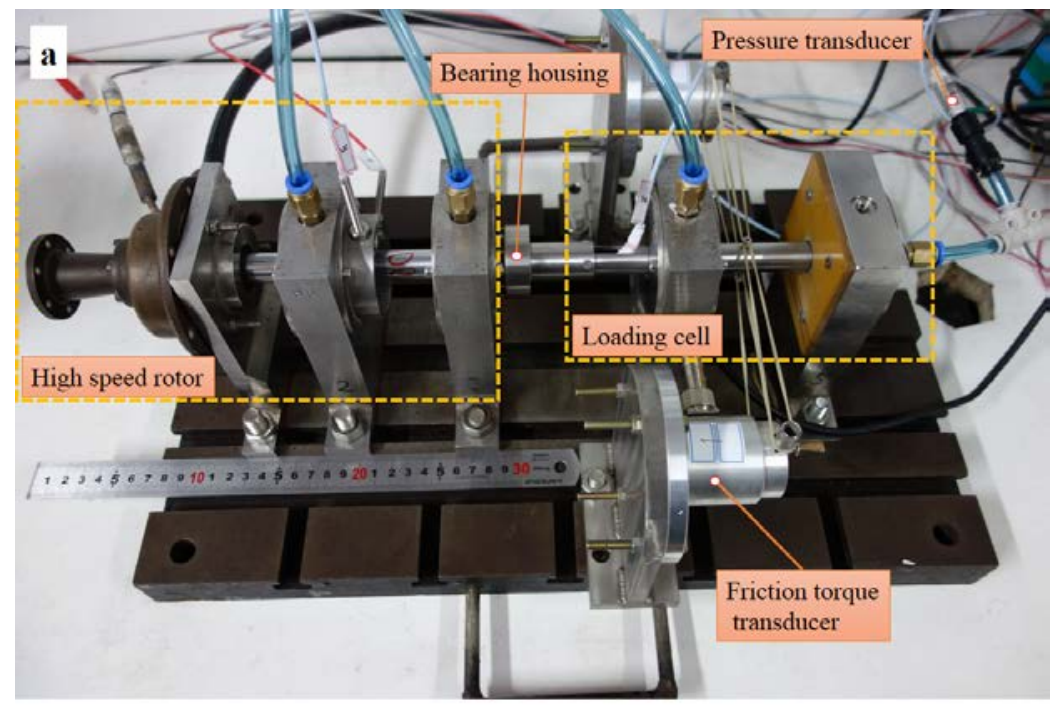

b

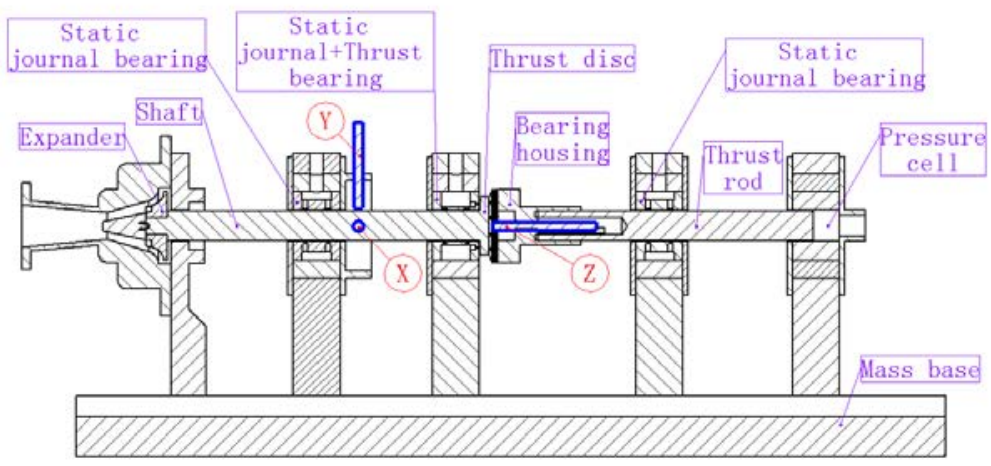

Fig. 4 a) Real picture and b) mechanical design of gas-driven thrust bearing test rig

\section{Testing procedure}

In static load-deflection test, hydrostatic journal bearing supply gas of $0.3 \mathrm{MPa}$ was provided. Loading cell pressure was increased until the thrust runner and thrust bearing were in mild contact. At this initial loading stage, load and deflection was quite sensitive due to partial contact of the foils. Then, more loads were added through loading cell to around $40 \mathrm{~N}$. Then, the bearing load was relieved to the initial load of $5.0 \mathrm{~N}$. In this loading and unloading process, load-deflection relation was recorded. More than three tests were conducted to ensure the repeatability of the data.

After smooth start-up and coast-down, transient loading test procedure was arranged as:

- Step 1: Verify the pressure at the hydrostatic journal bearing of the turbo-expander, turn up the expander supply gas to start the turbo-expander until its operation speed stabilized in the range from $40 \mathrm{krpm}$ to $100 \mathrm{krpm}$.

- Step 2: Exert more loads on the thrust bearing by increasing loading cell pressure. At the same time, tune the expander supply gas to preserve the rotational speed to be stable for at least 60 seconds. 
- Step 3: Repeat Step 2 until instability appears. In prevention of abrasion on the thrust runner, close the gas supply of turbo-expander. Then, turn off the gas supply for the hydrostatic journal bearings.

- Step 4: Dissemble the tested thrust bearing. If there was no abrasion on the thrust runner of tested foil thrust bearing, proceed to subsequent tests.

\section{Results and discussion}

\subsection{Static load deflection test}

In the foil thrust bearing design, compliance of supporting structure was essential for determination of bearing clearance and assembling preload. Static load and deflection relations of the three bearings were shown in Fig. 5 a). Due to the compliance of the foils, the initial load on the bearing was around $5.0 \mathrm{~N}$ for the ease of comparison. For the three bearings, the deflection in the loading process was smaller than that in unloading process, therefore hysteresis loops appeared. In the load range from $5.0 \mathrm{~N}$ to $20 \mathrm{~N}$, deflection of the bearing with $90^{\circ}$ pad was larger. When the load increased further, its deflection was smaller. The stiffness of the foil bearing could be derived from the slope of the load and deflection curve. Stiffness of the bearing in the loading tests was shown in Fig. $5 \mathrm{~b}$ ). In the load range from $5.0 \mathrm{~N}$ to $20 \mathrm{~N}$, the stiffness of the three bearings increased almost linearly with deflection, from $0.1 \mathrm{~N} \cdot \mu \mathrm{m}^{-1}$ to $0.25 \mathrm{~N} \cdot \mu \mathrm{m}^{-1}$. In this range, stiffness of the bearing with $90^{\circ}$ pad was a little bit smaller. Stiffness of the bearing with $60^{\circ}$ pad and $120^{\circ}$ still kept approximately linear relation with deflection when the bearing load increased further. In the transition from loading to unloading process, the calculated bearing stiffness increased sharply due to the friction between the foils. For the bearing with $90^{\circ}$, its stiffness increased remarkably in the load range from $20 \mathrm{~N}$ to $40 \mathrm{~N}$. In respect of mechanics, the compliances of the three bearings were the same for the idealized smooth foils.

a

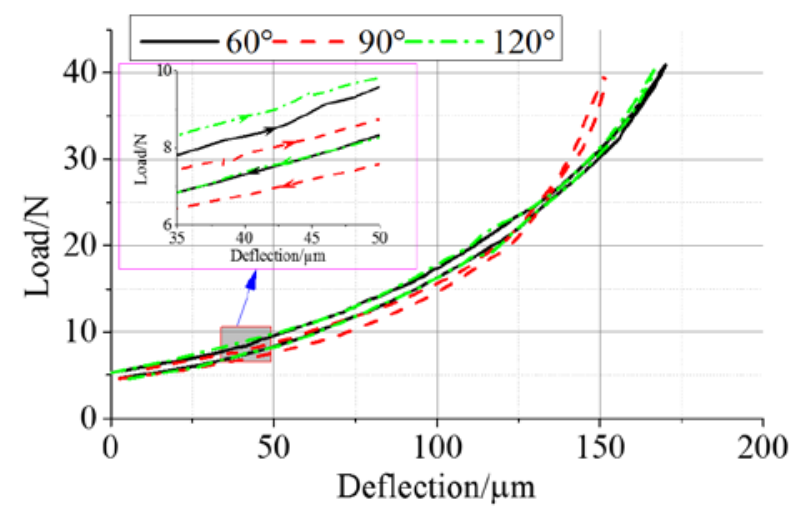

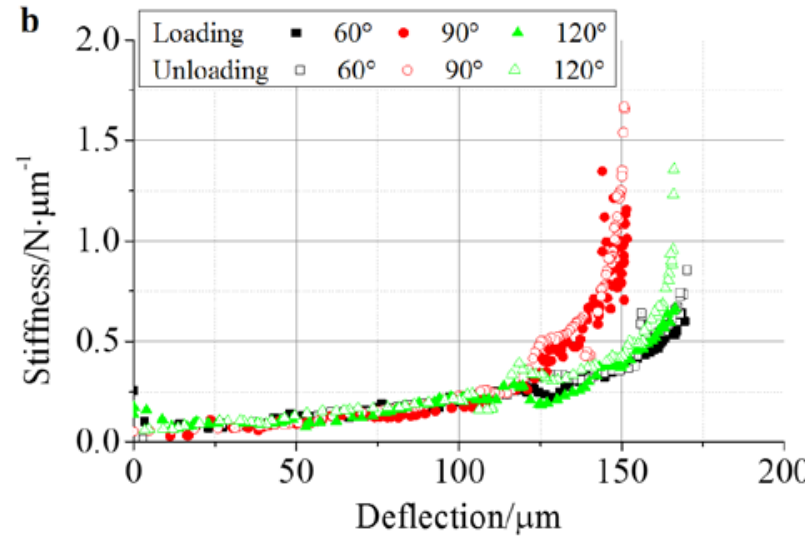

Fig. 5 a) Load-deflection and b) stiffness-deflection relations of MDPFTB with different number of thrust pads

Due to the pin distributions on the foils (refer to Fig. 2 and Fig. 3), there was a pin at the symmetric line of the $90^{\circ}$ foil. When there was a large deflection on the foil, the pin on both sides were not prone to move due to larger circumferential distance $\left(30^{\circ}\right)$ between the middle pin and the pin. For the bearing with $60^{\circ}$ and $120^{\circ}$ pad, there was no pin at the symmetric line, circumferential distance between the axial symmetric line and nearest pin location was $15^{\circ}$, and the foils were more prone to move in axial direction along with the pins. Due to the fixing pin assembly method, the foils could still move in radial direction. Hence, hysteresis loop appeared due to the friction effect. More than three tests were repeated to get the above results.

\subsection{Transient start-up and coast-down tests}

Transient start-up and coast-down processes of the bearings were of great significance in bearing application. In operation of foil thrust bearing, it was a combination of dry friction, mixed lubrication and gas lubrication. In transient processes, friction torque was an important indicator of bearing performance. For the three bearings, the relationship between friction torque and rotational speed were shown in Fig. 6. Before the lift-off of rotor from the bearing, there was a friction torque peak due to the friction transition from dry friction to gas lubrication. The start-up friction torque for the bearings with different thrust pad angles were around $2.5 \times 10^{-3} \mathrm{~N} \cdot \mathrm{m}$. The estimated lift-off speeds of the bearings were listed in Table 2. The lift-off speeds of the three bearings were around $20 \mathrm{krpm}$. After lift-off of the rotor from the bearing, the friction torque of the bearing increased with rotor speed and displays obvious speed dependent 
characteristics. When the rotor speed reached $100 \mathrm{krpm}$, the supply gas was reduced gradually to decrease the rotor speed. When the rotor speed decreased to around $20 \mathrm{krpm}$, the thrust runner touched the thrust bearing surface and another friction torque peak appeared. For the bearings, the touch-down speed was a little bit larger than the lift-off speed; consequently the friction torque at touch-down was larger than that at lift-off.

a

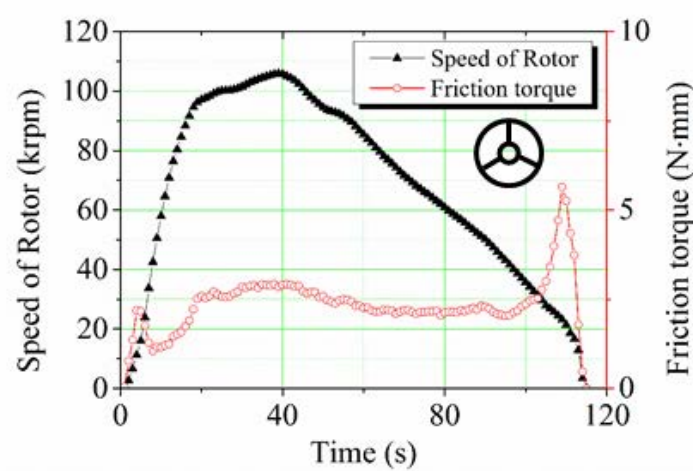

b

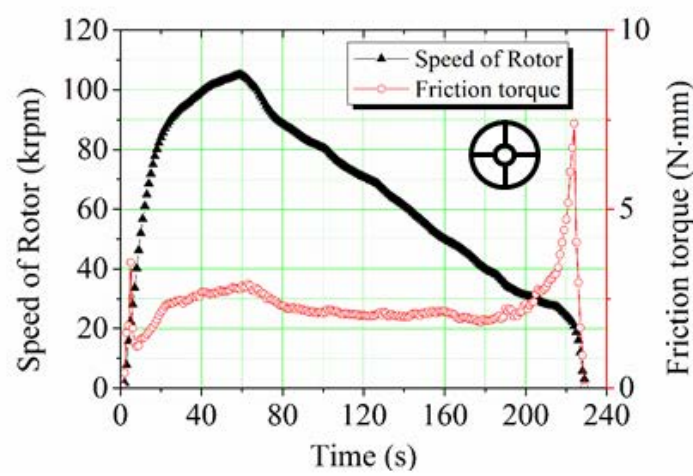

c

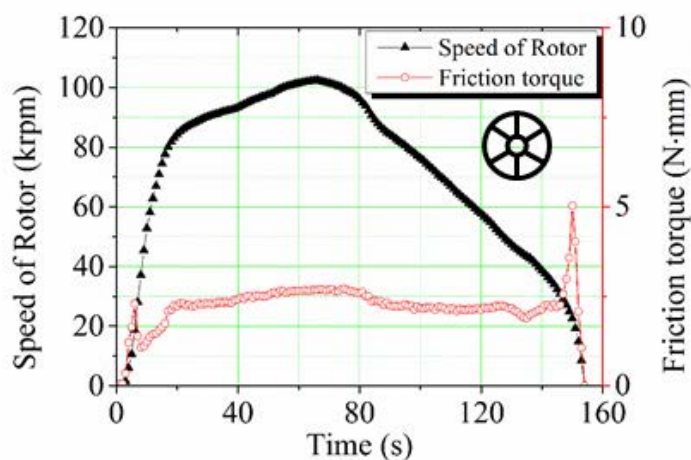

Fig. 6 Friction torques and rotor speed of the thrust bearing with angular extent of a) $120^{\circ}$; b) $90^{\circ}$; c) $60^{\circ}$

The relative displacement between the thrust runner and the thrust bearing surface was shown in Fig. 7. In the speed-up process, the friction between the foils hindered the deformation of the foils and thinner gas film was generated. Therefore, thinner gas film took shape. The relative displacement in $\mathrm{Z}$ direction was smaller in the speed-up process than that in coast-down process. Around lift-off speed of $20 \mathrm{krpm}$, relative displacement in Z direction was smaller for the $90^{\circ}$ foil bearing, hence larger friction torque existed in Fig. 6. For the bearing with $120^{\circ}$ angular span, the displacement difference between speed-up and coast-down was smaller in the speed range of 40 80 krpm. The displacement difference was noticeable in higher speed range. For the $90^{\circ}$ foil bearing, difference became more obvious when the speed was larger than $35 \mathrm{krpm}$. For the bearing with $60^{\circ}$ angular span, the difference was prominent in the whole speed range. Under a mild load, the relative displacement in $\mathrm{Z}$ direction was larger and more obvious with more thrust pad partitions at the same rotor speed. It was conclusive that more pad partitions was preferred among the three bearings. Thereby, more safety allowance was obtained in high speed operation. 
Table 2 Lift-off and touch-down speed of the three bearings with preload of $5.0 \mathrm{~N}$

\begin{tabular}{c|c|c}
\hline \hline Partition angular span/ $^{\circ}$ & Lift-off speed/krpm & Touch-down speed/krpm \\
\hline 60 & $10 \sim 15$ & $\sim 23$ \\
\hline 90 & $\sim 20$ & $\sim 21$ \\
\hline 120 & $\sim 19$ & $\sim 23$ \\
\hline
\end{tabular}

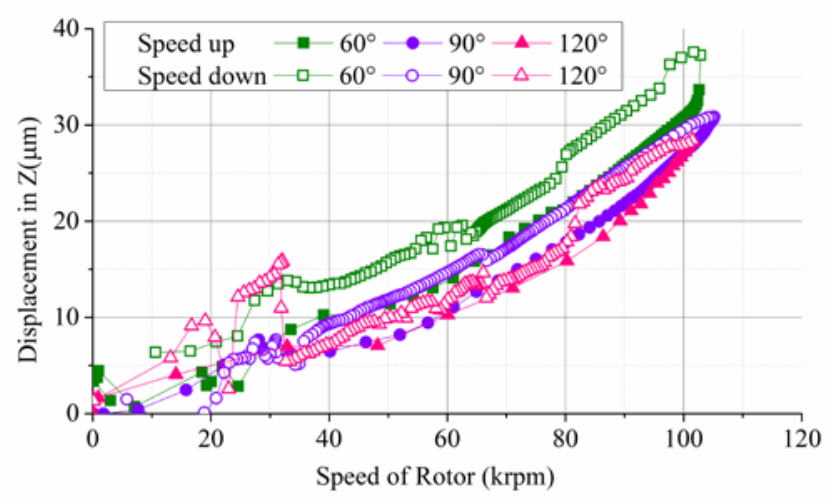

Fig. 7 Relative displacements between runner and thrust bearings with different angular extents

In above transient processes, rotor vibration in $\mathrm{X}, \mathrm{Y}$ and $\mathrm{Z}$ directions were monitored. Vibration signals were filtered and analyzed using FFT method (Fast Fourier Transfer). Spectrum cascade plots of the three bearings in $\mathrm{X}$ direction were shown in Fig. 8 a), b) and c). From the spectrum cascade plot, it was easier to figure out that there was a vibration peak at around $20 \mathrm{krpm}$ for the three bearings, which implied the first critical speed of rotor-bearing system. With increase of rotor speed, vibration amplitude in $\mathrm{X}$ increased due to unbalance responses of rotor. For the three bearings, there were speed-independent non-synchronous vibrations in higher speed range.

The non-synchronous vibrations of the three bearings at speed around $102 \mathrm{krpm}$ were compared in Fig. 9. Three obvious non-synchronous vibrations were: $\sim 50 \mathrm{~Hz}, \sim 330 \mathrm{~Hz}$ and $\sim 720 \mathrm{~Hz}$. There were small differences at $\sim 330 \mathrm{~Hz}$ for the three bearings with a closer look. The maximal vibration amplitude of the three bearings was proportional to the bearing static stiffness with small deflection (referring to local enlarged view in Fig. 5 a)). In addition, higher vibration amplitude was observed for more compliant $90^{\circ}$ bearing. For the non-synchronous vibrations $\sim 720 \mathrm{~Hz}$, the vibration amplitude was proportional to the bearing static stiffness with larger deflection (referring to Fig. 5 a)).

Rotor locus/orbit was another important indicator of stable operation. Due to similar rotor locus of the three bearings in speed up process, only $90^{\circ}$ bearing was listed. The rotor locus with $90^{\circ}$ bearing at speeds of $7 \mathrm{krpm}, 30$ krpm, $65 \mathrm{krpm}$ and $105 \mathrm{krpm}$ were listed in Fig. 10. With increase of rotor speed, the rotor locus became smoother. At around $30 \mathrm{krpm}$, the vibration amplitude in $\mathrm{X}$ and $\mathrm{Y}$ directions were larger than those at $7 \mathrm{krpm}$ and $65 \mathrm{krpm}$, which corresponded to one critical speed of the rotor-bearing system. Although there were non-synchronous vibrations in most of the speed range, the rotor locus maintained good repeatability. Therefore, in above testing speed ranges, the non-synchronous vibrations did not cause unstable operation or failure. 

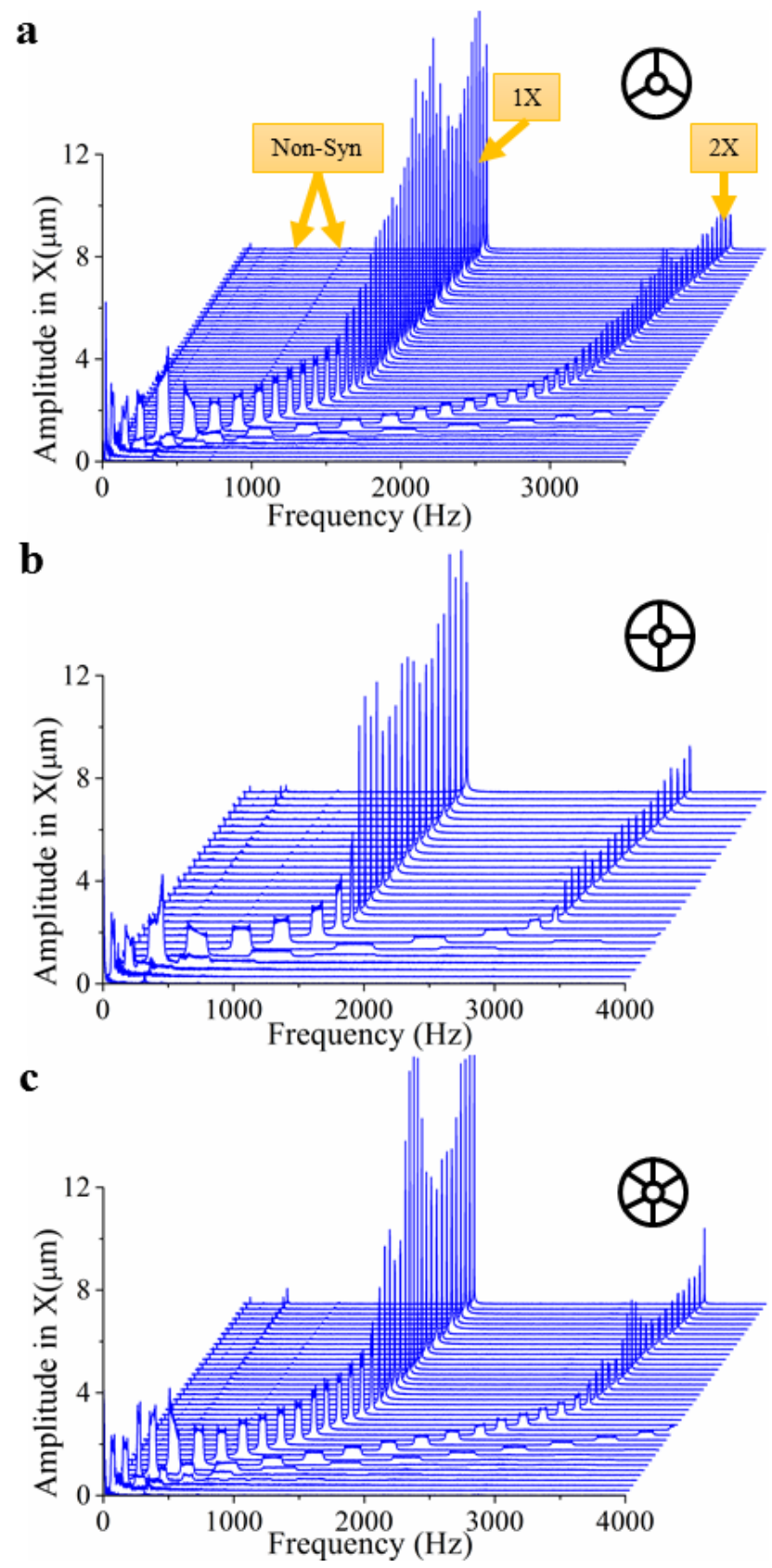

Fig. 8 Spectrum cascades of high speed rotor with a) $120^{\circ}$ bearing; b) $90^{\circ}$ bearing; c) $60^{\circ}$ bearing 


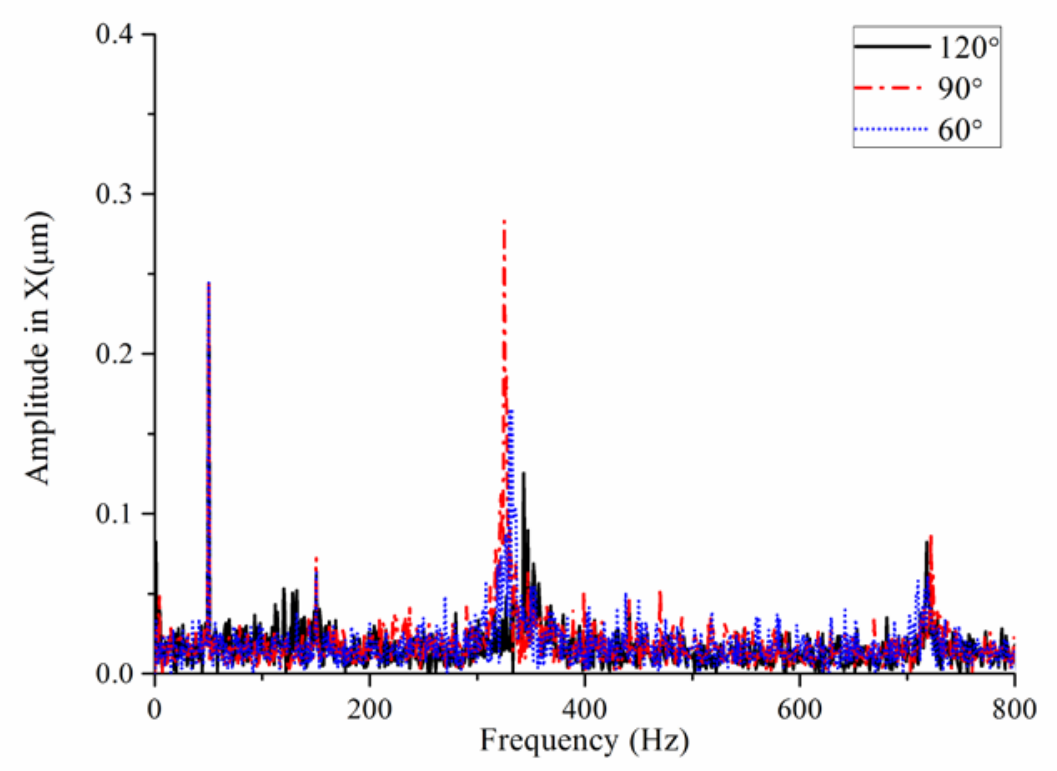

Fig. 9 Non-synchronous vibrations of high speed rotor with bearings of different angular extents

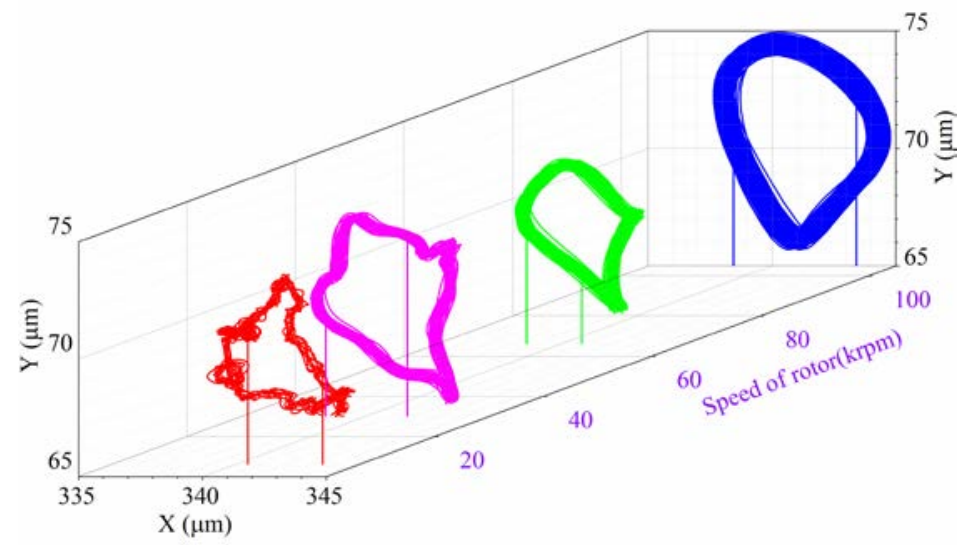

Fig. 10 Rotor locus of high speed rotor with $90^{\circ}$ bearing in speed-up process

The vibration in $\mathrm{X}, \mathrm{Y}$ and $\mathrm{Z}$ directions at main frequency were compared in Fig. $11 \mathrm{a}$ ), b) and c). At the first critical speed around $20 \mathrm{krpm}$, the vibration amplitude of the bearing with $90^{\circ}$ angular span was a little bit larger than the other two bearings. In high speed range larger than $80 \mathrm{krpm}$, the vibration amplitude of the main frequency was strongly related to the angular span of the thrust pad. The vibration amplitudes in $\mathrm{X}, \mathrm{Y}$ and $\mathrm{Z}$ directions were suppressed quite well for the bearing with narrower angular span. The second critical speed appeared around $90 \mathrm{krpm}$ for the bearing with $120^{\circ}$ angular span. For the bearing with $90^{\circ}$ and $60^{\circ}$ angular span, the second critical speed were $95 \mathrm{krpm}$ and 100 krpm, respectively. In this experiment, the hydrostatic journal bearing did not change and the difference of vibration amplitude and critical speeds in $\mathrm{X}$ and $\mathrm{Y}$ directions were affected by the thrust bearing prominently. Namely, stiffness of thrust bearing ( $\mathrm{Z}$ direction) had a coupled effect on the second and higher order critical speeds in $\mathrm{X}$ and $\mathrm{Y}$ directions in higher frequency domain. The vibration amplitudes of main frequency in $Z$ direction were around $3 \mu \mathrm{m}$ for the three bearings in the whole operation speed. When rotor speed was larger than $80 \mathrm{krpm}$, vibration amplitude in $\mathrm{Z}$ direction had a similar trend with those in $\mathrm{X}$ and $\mathrm{Y}$ directions. 
a

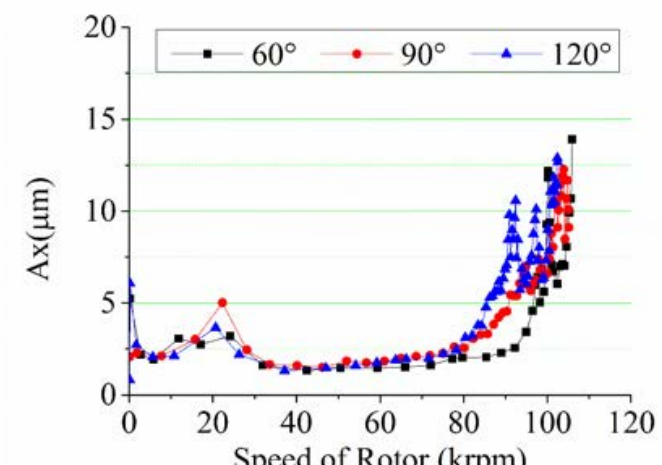

b

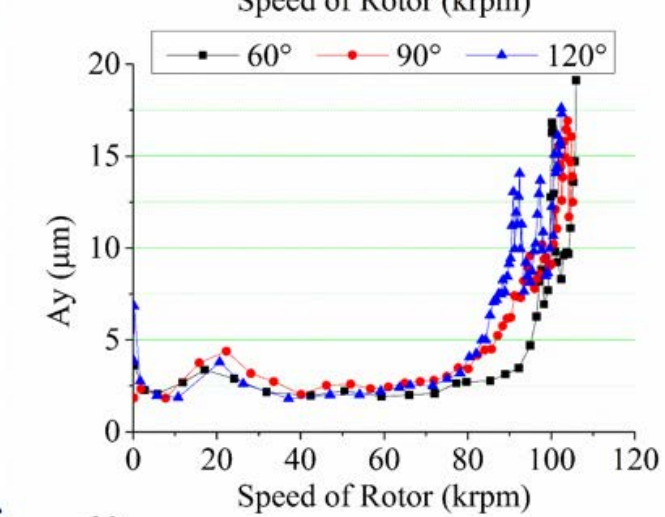

c

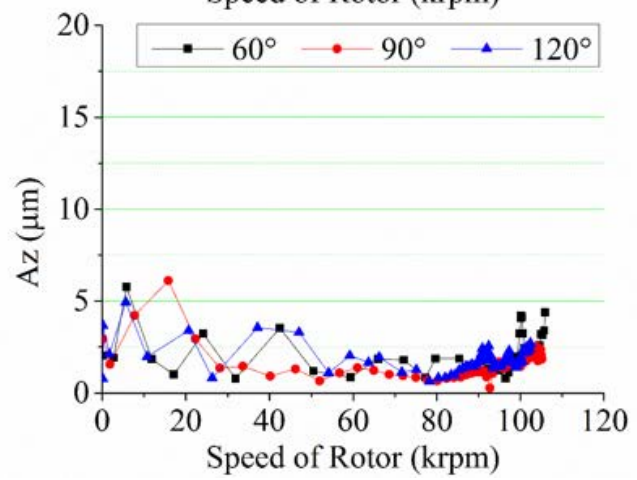

Fig. 11 Vibration amplitudes of main frequencies in a) $\mathrm{X}$ direction b) $\mathrm{Y}$ direction and c) $\mathrm{Z}$ direction in transient speed-up under preload of $5.0 \mathrm{~N}$

\subsection{Transient loading tests}

In transient loading test, relative displacement between thrust pad and bearing, turbine supply pressure and friction torque under load of $10.5 \mathrm{~N}$ were shown in Fig. $12 \mathrm{a}$ ), b) and c), respectively. With bearing load of $10.5 \mathrm{~N}$, the available operational speed was almost the same for bearings with 4 and 6 pads, i.e. from $40 \mathrm{krpm}$ to $115 \mathrm{krpm}$. In a), the rotational speed increased almost linearly with supply pressure. In b), the relative displacement in Z direction was higher for bearing with more pad partitions. For the three bearings, relative displacement in $\mathrm{Z}$ direction was smaller for the bearing with wider angular pad. The trend was similar to the results under load of $5.0 \mathrm{~N}$. Friction torque of the three bearings were compared in c). Although the relative displacement between thrust bearing and thrust runner was smaller for the bearing with $120^{\circ}$ thrust pad, its friction torque was smaller comparing to the bearing with $90^{\circ}$ pad. It is more stable under different rotor speeds comparing to two other bearings. This may be affected by pressure distributions in the bearing that need further experimental or numerical analysis. 
$\mathbf{a}$

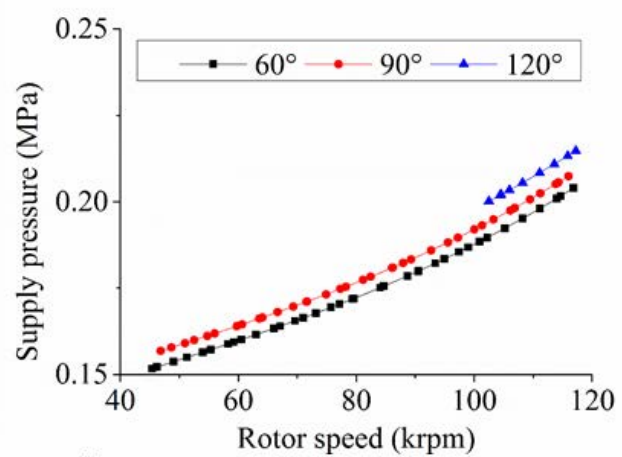

b

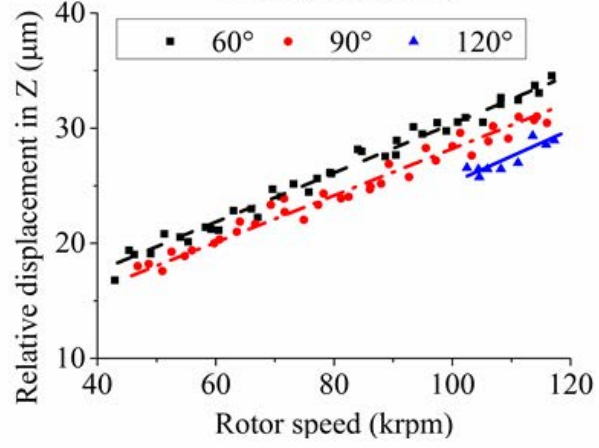

c

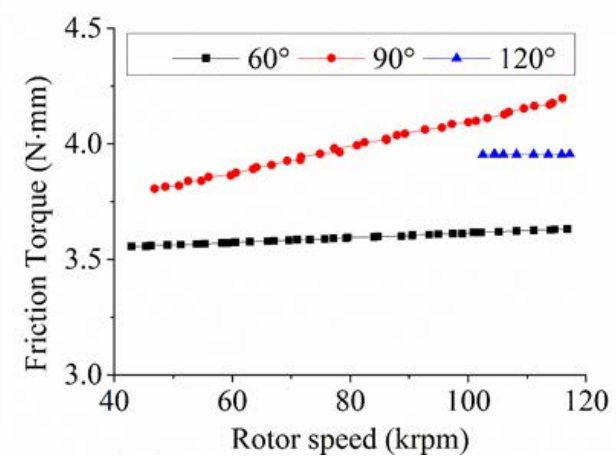

Fig. 12 a) Supply pressure; b) relative displacement in $\mathrm{Z}$ and c) friction torque of the bearings under load of $10.5 \mathrm{~N}$

The load capacities of the three bearings were shown in Fig. 13. Before ultimate load capacity was reached, load capacity of the thrust bearing increased with rotational speed due to hydrodynamic effect. For the bearing with 3 pads, its load capacity did not make any changes around $5.0 \mathrm{~N}$ in the speed range from $45 \mathrm{krpm}$ to $75 \mathrm{krpm}$. In higher rotational speed range, bearing load capacity increased in a stepwise pattern. Bearing load capacity reached around 10 $\mathrm{N}$ at $105 \mathrm{krpm}$. At speed around $120 \mathrm{krpm}$, bearing load capacity reached $12 \mathrm{~N}$. For the bearing with 4 pads, the rotational speed maintained stable around $25 \mathrm{~N}$ in the speed range from $75 \mathrm{krpm}$ to $106 \mathrm{krpm}$. Bearing load capacity declined when rotational speed exceeded $106 \mathrm{krpm}$. For the bearing with 6 pads, its load capacity increased almost linearly with rotational speed in low speed range from $50 \mathrm{krpm}$ to $70 \mathrm{rpm}$. As rotational speed increased further, the load capacity maintained around $32.5 \mathrm{~N}$. When rotational speed exceeded $100 \mathrm{krpm}$, the bearing load capacity descended gradually. In general, the bearing with 6 pads provided higher bearing load capacity at the same rotational speed. The available operation speed range with maximal bearing load was narrower compared with 4 pads bearing.

In the whole operation speed range, the thrust bearing with larger thrust pad range produced higher stiffness and less elastic axial deflections due to more supporting projections in each thrust pad. However, more partition of the thrust pad was conducive for local converging fluid formation. In high speed range, load capacities of the bearings were weakened which implied a deficiency in supporting stiffness. Thus, for future improvement, more appropriate projection distribution was suggested to provide higher load capacity for high speed operation. 


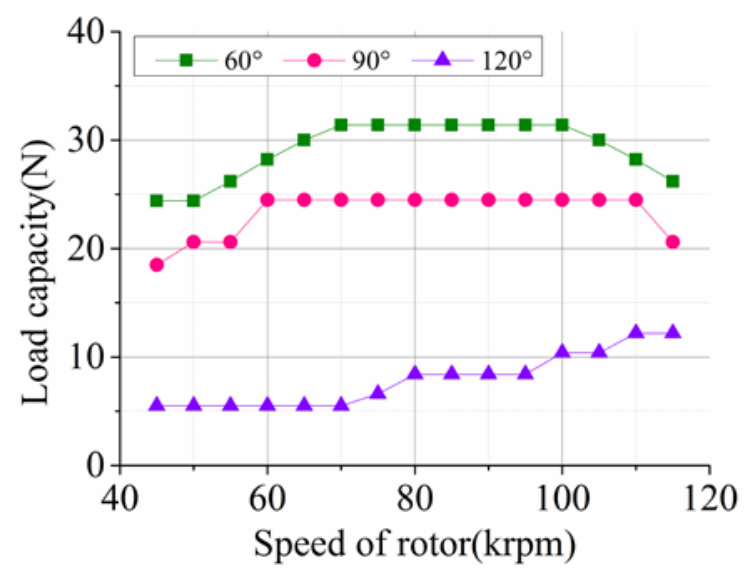

Fig. 13 Load capacities of the thrust bearings with different pad numbers

The foils after tests were shown in Fig. 14. The diameter of thrust runner was smaller than that of top foil. There were slight abrasions on the top foil inside the fixing pins due to the dry friction between thrust runner and top foil during the start-up and coast-down processes. Start and stop of the foil thrust bearings were tested repeatedly to ensure the reliability of the test data. Due to existing testing condition and foil installation method, only three patterns of bearings were tested. This did not come to the arbitrary conclusion that the bearing with more thrust pads would outperform in real operation. There were quite a lot of factors influencing the bearing performance. Further experimental investigations were expected to shed more lights on the characteristics of protuberant foil thrust bearing.

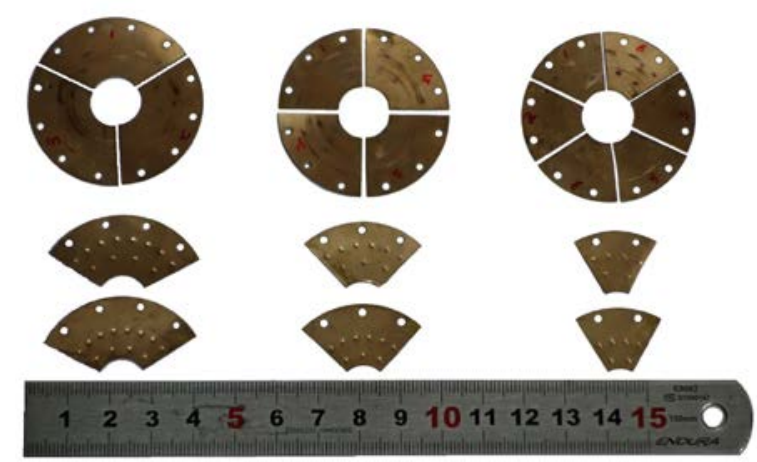

Fig. 14 Foils of the tested three thrust bearings

\section{Conclusions}

In order to facilitate the application of protuberant foil thrust bearing, effects of thrust pad partition on the static stiffness and transient loading of the bearing were evaluated. Performance characteristics of the rotor-bearing system with different thrust pad partitions were compared. The results could be summarized as follows.

1. For protuberant foil thrust bearing, the static stiffness increased with the bearing load. Proper partition of the thrust pad could improve the bearing stiffness under higher load. Meanwhile, with respect to the rotor-bearing system, the axial supporting had insignificant effect on the lower order critical speed in the radial direction. However, in higher speed range, more thrust pads could increase the second and higher critical speeds and suppress the vibration amplitude;

2. Under the same load, hydrodynamic effect was more prominent with more partitions of thrust surface. The ultimate load capacity of the bearing increased with thrust pads. However, the available operational speed range was narrowed down. For the bearing with more thrust pads, load capacity decreased earlier in high speed range with softer static stiffness. Available operating range with maximal load capacity could be extended with appropriate thrust pad partition;

3. In the transient start-up and touching-down test, both lift-off speed and corresponding friction torque were 
insensitive to the thrust pad partition. Friction torque of the bearing displayed speed-dependent characteristics in gas lubrication regime. Peak friction torque at touching-down speed was a little bit larger than that at the lift-off speed. For the three bearings, more partitions of thrust pad could lead to a larger relative displacement in axial direction.

\section{Acknowledgement}

This project was supported by the National Nature Science Foundation of China (51406157), the China Postdoctoral Science Foundation (2014M552438) and the Fundamental Research Funds for the Central Universities.

\section{References}

Agrawal, G. L., Foil air/gas bearing technology - an overview(1997), ASME Paper No. 97-GT-347.

Balducchi, F., Arghir, M., Gauthier, R. and Renard, E., Experimental analysis of the start-up torque of a mildly loaded foil thrust bearing, ASME Journal of Tribology, Vol.135, No.3 (2013), pp.031702-1-7.

Dellacorte, C., A new foil air bearing test rig for use to $700^{\circ} \mathrm{C}$ and $70,000 \mathrm{rpm}$, Tribology Transactions, Vol.41, No.3 (1998), pp.335-340.

DellaCorte, C., Radil, K. C., Bruckner, R. J. and Howard, S.A., Design, fabrication, and performance of open source generation I and II compliant hydrodynamic gas foil bearings, Tribology Transactions, Vol.51, No.3(2008), pp.254-264.

Dykas, B., Bruckner, R., Dellacorte, C., Edmonds, B. and Prahl, J., Design, fabrication, and performance of foil gas thrust bearings for microturbomachinery applications, ASME Journal of Engineering for Gas Turbines and Power, Vol.131, No.1 (2009), pp.012301-1-8.

Heshmat, H., Walowit, J. A. and Pinkus, O., Analysis of gas lubricated compliant thrust bearings, ASME Journal of Tribology, Vol.105, No.4 (1983), pp.638-646.

Hou, Y., Zhu, Z. H. and Chen, C. Z., Comparative test on two kinds of new compliant foil bearing for small cryogenic turbo-expander, Cryogenics, Vol.44, No.1(2004), pp.69-72.

Hou, Y., Ma, B., Yang, S.J., Chen, X. Y., Zheng, Y. Q. and Chen, S. T., Experimental study on bump-foil gas bearing with different diametric clearance configurations, Journal of Mechanical Science and Technology, Vol.29, No.5(2015), pp.2089-2095.

Howard, S. A., Dellacorte, C., Valco, M. J., Prahl, J.M. and Heshmat, H., Steady-state stiffness of foil air journal bearings at elevated temperatures, Tribology Transactions, Vol.44, No.3(2001a), pp.489-493.

Howard, S. A., Dellacorte, C., Valco, M. J., Prahl, J. M., and Heshmat, H., Dynamic stiffness and damping characteristics of a high-temperature air foil journal bearing, Tribology Transactions, Vol.44, No.4(2001b), pp.657-663.

Hughes, S. J., Hogg, S. I. and Jones T. V., Analysis of a gas lubricated hydrodynamic thrust bearing. Journal of Tribology-Transactions of the ASME, Vol.118, No.3(1996), pp. 449-456.

Kim, D., Parametric studies on static and dynamic performance of air foil bearings with different top foil geometries and bump stiffness distributions, ASME Journal of Tribology, Vol.129, No.2(2006), pp.354-364.

Kim, T. H. and Andres, L. S., Limits for high-speed operation of gas foil bearings, ASME Journal of Tribology, Vol.128, No.3( 2006), pp.670-673.

Kim, T. H., Lee, Y. B., Kim, T. Y. and Jeong, K. H., Rotordynamic performance of an oil-Free turbo blower focusing on load capacity of gas foil thrust bearings, ASME Journal of Engineering for Gas Turbines and Power, Vol.134, No.2(2011), pp.022501-7.

$\mathrm{Ku}, \mathrm{C}$. P. R.and Heshmat, H., Compliant foil bearing structural stiffness analysis, part I-theoretical model including strip and variable bump foil geometry, ASME Journal of Tribology, Vol.114, No.2(1992), pp.394-400.

Ku, C. P. R., Heshmat, H., Compliant foil bearing structural stiffness analysis, part II: Experimental investigation, ASME Journal of Tribology, Vol.113(1993), pp. 364-369.

Lai, T. W., Chen, S. T., Ma, B., Zheng, Y. Q. and Hou, Y., Effects of bearing clearance and supporting stiffness on performances of rotor-bearing system with multi-decked protuberant gas foil journal bearing, Proceedings of the Institution of Mechanical Engineers, Part J: Journal of Engineering Tribology, Vol.228, No.7(2014), pp. $780-788$.

Lee, D. and Kim, D., Design and performance prediction of hybrid air foil thrust bearings, ASME Journal of Engineering for Gas Turbines and Power, Vol.133, No.4( 2010), 042501, pp.1-13. 
Peng, Z. C. and Khonsari, M. M., On the limiting load-carrying capacity of foil bearings, ASME Journal of Tribology, Vol.126, No.4(2004), pp. 817-818.

Rubio, D. and Andres, L. S., Structural stiffness, dry friction coefficient, and equivalent viscous damping in a bump-type foil gas bearing, ASME Journal of Engineering for Gas Turbines and Power, Vol.129, No.2(2006), pp.494-502.

Rudloff, L., Arghir, M., Bonneau, O. and Matta, P., Experimental analyses of a first generation foil bearing: startup torque and dynamic coefficients, ASME Journal of Engineering for Gas Turbines and Power, Vol.133, No.9(2011), 092501, pp.1-9.

Ryu, K. and Andres, L. S., On the failure of a gas foil bearing: high temperature operation without cooling flow, ASME Journal of Engineering for Gas Turbines and Power, Vol.135, No.11(2013), 112506, pp.1-10, Paper No. GTP-13-1254.

Sim, K. H., Lee, Y. B., Jang, S. M. and Kim, T. H., Thermal analysis of high-speed permanent magnet motor with cooling flows supported on gas foil bearings: part I - coupled thermal and loss modeling, Journal of Mechanical Science and Technology, Vol.29, No.12(2015a), pp.5469-5476.

Sim, K. H., Lee, Y. B., Jang, S. M. and Kim, T. H., Thermal analysis of high-speed permanent magnet motor with cooling flows supported on gas foil bearings: part II - bearing modeling and case studies, Journal of Mechanical Science and Technology, Vol.29, No.12(2015b), pp.5477-5483.

Sim, K. H., Lee, Y. B., Song, J. W., Kim, J. B. and Kim, T. H., Identification of the dynamic performance of a gas foil journal bearing operating at high temperatures, Journal of Mechanical Science and Technology, Vol.28, No.1(2014), pp.43-51.

Somaya, K., Yoshimoto, S. and Miyatake, M., Load capacity of aerodynamic foil thrust bearings supported by viscoelastic material, Proceedings of the Institution of Mechanical Engineers, Part J: Journal of Engineering Tribology, Vol.223, No.4(2009), pp.645-652.

Zhou, Q., Hou, Y. and Chen, C. Z., Dynamic stability experiments of compliant foil thrust bearing with viscoelastic support, Tribology International, Vol.42, No.5(2009), pp.662-665.

Zhou, Q., Hou, Y. and Chen, R. G., Development of foil thrust bearings with simple structure for micro turbines, Advanced Materials Research, Vol.368-373(2011), pp.1392-1395. 